\title{
Correction to: The role of redox system in metastasis formation
}

\author{
Chiara Cencioni ${ }^{\cdot}$ Valentina Comunanza ${ }^{2,3} \cdot$ Emanuele Middonti $^{2,3} \cdot$ Edoardo Vallariello $^{2,3} \cdot$ Federico Bussolino $^{2,3}$ (1)
}

Published online: 8 July 2021

(c) The Author(s) 2021

\section{Correction to: Angiogenesis https://doi.org/10.1007/s10456-021-09779-5}

In the original publication, the affiliation information of the authors was processed incorrectly. It has been updated in this correction.

Open Access This article is licensed under a Creative Commons Attribution 4.0 International License, which permits use, sharing, adaptation, distribution and reproduction in any medium or format, as long as you give appropriate credit to the original author(s) and the source, provide a link to the Creative Commons licence, and indicate if changes were made. The images or other third party material in this article are included in the article's Creative Commons licence, unless indicated otherwise in a credit line to the material. If material is not included in the article's Creative Commons licence and your intended use is not permitted by statutory regulation or exceeds the permitted use, you will need to obtain permission directly from the copyright holder. To view a copy of this licence, visit http://creativecommons.org/licenses/by/4.0/.

Publisher's Note Springer Nature remains neutral with regard to jurisdictional claims in published maps and institutional affiliations.

The original article can be found online at https://doi.org/10.1007/ s10456-021-09779-5.

Federico Bussolino

federico.bussolino@ircc.it

1 Institute for Systems Analysis and Computer Science "A. Ruberti", National Research Council (IASI-CNR), 00185 Rome, Italy

2 Department of Oncology, University of Torino, 10043 Orbassano, Italy

3 Candiolo Cancer Institute, FPO - IRCCS, 10060 Candiolo, Italy 